\title{
The Mechanism of Apomixis in Pennisetum Giliare
}

\author{
L. A. Snyder ${ }^{1}$, Alice R. Hernández ${ }^{2}$, and H. E. Warmke ${ }^{3}$
}

\section{INTRODUCTION}

Pennisetum citiare (L.) Link is an extremely polymorphic species having an extensive native range which extends over much of Africa, Madagascar, Sicily, and eastward to Palestine, India, and Java. The species has been introduced into Australia and the Americas. In Puerto Rico it is now a major component of the flora in savanna areas of the semiarid southern coastal region $(2)^{4} . P$. ciliare has recently received appreciable attention in some areas of the southern United States because of the occurrence of desirable forage ecotypes adapted to arid and semiarid habitats. Interest in the species in Puerto Rico has resulted primarily from the introduction of strains agronomically superior to those already established on the Island.

Meiotic irregularities encountered in a study of microsporogenesis in a number of introduced strains of $P$. ciliare, and the marked uniformity of progenies grown from bulk-collected seed which originated from a number of different localities, initially suggested the possibility of apomictic reproduction within this highly variable species. The preliminary study of sectioned material of developing ovules indicated the occurrence of appreciable irregularity, and the present investigation was undertaken to study the mechanism of reproduction in the species, with particular reference to megasporogenesis and megagametogenesis.

\section{MATERIAL AND METHODS}

Seeds of 13 strains of $P$. ciliare, representing various parts of the native range of the species, were obtained through the cooperation of Edwin James of the Southern Regional Plant Introduction Station, Experiment, Ga. The initial observations were made on field-grown plants of these strains and plants of a "native" strain which originated from material collected near Salinas, P. R., by Ovidio García Molinari. The principal source of material for the present investigation was a strain of $P$. ciliare collected near Tamale, Gold Coast (P.I. 185641) $)^{5}$. Supplementary data were obtained

1 Formerly of the Federal Experiment Station, U. S. Department of Agriculture, Mayagüez, P. R.

${ }^{2}$ Research Assistant in Cytology, Agricultural Experiment Station of the University of Puerto Rico, Río Piedras, P. R.

${ }^{3}$ Director, Federal Experiment Station, U. S. Department of Agriculture, Mayagüez, P. R.

${ }^{4}$ Numbers in parentheses refer to Literature Cited, p. 164.

5 P.I. numbers refer to accession numbers of the Section of Plant Exploration and Introduction, USDA. 
from material of the Puerto Rican strain and from strains originating in Southern Rhodesia (P.I. 156540 and 203521), Ethiopia (P.I. 197443), Morocco (P.I. 202513), East Punjab, India (P.I. 164414), and Western Australia (P.I. 193445).

Although $P$. ciliare is an extremely polymorphic species, most of the strains studied, as well as a number of additional strains growing in the same nursery, exhibited marked intrastrain uniformity. Two exceptions, which might be expected in view of the fact that the progenies were grown from bulk-collected seeds, were P.I. 164414 and 202513. The culture of the latter strain included plants of two distinctly different morphological types, both of which were identified as P. ciliare. The culture of P.I. 164414 contained plants of at least three different morphological types, one of which was identified by Ernest R. Sohns, of the U. S. National Herbarium, as Cenchrus setigerus Vahl. Because of the similarity of this material (considered part of the same agamic complex by Fisher, et al. (1) pertinent data from this species have been treated along with $P$. ciliare. Herbarium specimens of the various strains of $P$. citiare involved in the investigation, and of the C. setigerus material, have been deposited in the U. S. National Herbarium.

Immature inflorescences for the study of microsporogenesis were fixed in a 3:1 mixture of 95-percent alcohol and glacial acetic acid for 24 hours and then washed and stored in 70-percent alcohol. Individual florets were not dissected from the inflorescences, but the material was aspirated immediately after being placed in the fixative to facilitate penetration of the solution. Analyses of meiotic behavior were made from temporary iron-acetocarmine smears.

Material for the study of megasporogenesis and megagametogenesis was killed in formalin-acetic-alcohol (70-percent alcohol) after the florets had been dissected from the inflorescences and the distal one-third of the lemma and palea had been out off to facilitate penetration of the fixative. For stages after anthesis, the glumes and lemma were removed prior to embedding, because the nerves of the second glume and the lemma become sufficiently indurate at this stage to cause difficulty in sectioning. The florets were embedded in paraffin by the normal-butyl alcohol method. Sectioning was done at 15 micra, and the material was stained in from hematoxylin.

Pollination studies were made with inflorescences that had been bagged about 56 hours before anthesis. Bagging was necessitated by the fact that the stigmas of $P$. ciliare florets are exserted and apparently receptive as early as 36 to 48 hours before anthesis. The bags were removed at the time of anthesis, and all florets whose anthers had not dehisced within 10 minutes after the first pollen was shed were removed from the inflorescence. The stigmas were removed completely from the remaining florets at various 
intervals after anthesis. Examination of the treated florets to determine the percentages of seeds set was made prior to maturity and shattering of the inflorescence.

\section{OBSERVATIONS}

\section{MICROSPOROGENESIS}

Hernández (3) has reported chromosome numbers of $2 n=36$ for five strains of $P$. ciliare, including a strain from Puerto Rico, and $2 n=54$ for a sixth strain. Fisher, et al. (1) investigated strains of the species with chromosome numbers of $2 n=32,36,40$, and 54 , and found $2 n=36$ in all material of $C$. setigerus that they studied. Incidental to a study of microsporogenesis in several strains of $P$. ciliare, we have verified the number $2 n=36$ in two of the collections reported earlier by Hernández, the Puerto Rican strain and P.I. 193445, and have found the same number in three other unreported collections, P.I. 185641, 197443, and 203521. In addition, a single plant of P.I. 202513 was studied and found to have $2 n=43$, and two plants of P.I. 156540 exhibited $2 n=48$. The only material of $C$. setigerus studied in the present investigation was from the collection P.I. 164414 , and had the chromosome number $2 n=36$.

Meiotic behavior was studied in four plants of P.I. 185641, the strain from which the major part of the material used in the investigation of megasporogenesis and megagametogenesis was obtained. Although Fisher, et al. (1) reported no irregularity at meiosis in the 36-chromosome types, those investigated in the present study showed considerable irregularity. Most of the microsporocytes examined at diakinesis and first metaphase contained 2-4 quadrivalents. The maximum chromosome association observed in an aggregate sample of several hundred cells was $5_{\text {IV }}+8_{\text {II }}$. The mean numbers of various chromosome configurations, based on the analysis of 106 diakinesis cells from one of the plants, were: $2.7_{\mathrm{IV}}, 0.1_{\mathrm{III}}, 12.0_{\mathrm{II}}$, and $0.9_{\mathrm{I}}$. From 1 to 5 univalents were found in 39 percent of the cells analyzed. Lagging chromosomes were present in 36 percent of the first anaphase figures examined, with usually only one or two univalent chromosomes exhibiting lagging in a given cell. Of 59 late anaphase figures in which the complete chromosome complement could be counted, and which showed no evidence of lagging chromosomes, 34.5 percent were found to have unbalanced distributions of the 36 chromosomes, i.e., 17 to 19 and 16 to 20 disjunctions. The second meiotic division exhibited greater regularity than did the first, and only 14 percent of the sporads (or tetrads of microspores) examined contained micronuclei. Chromosome pairing and the other aspects of meiosis were very similar in the four plants studied, and pollen stainability in iodinepotassium iodide or acetocarmine was 52 to 60 percent in each of the plants. 
Chromosome association at diakinesis and first metaphase in plants of the five additional 36-chromosome strains was found to be essentially comparable to that in P.I. 185641, although some variation was observed from strain to strain. The frequencies of first anaphase figures with lagging chromosomes were within the range of 30 to 40 percent for P.I. 193445, 197443, and 203521. On the other hand, the Puerto Rican strain and P.I. 164414, both of which had lower univalent frequencies than the other 36-chromosome strains, had lagging chromosomes in only 10 to 14 percent of the first anaphase cells examined. Satisfactory material for the study of nondisjunction was available only for the Puerto Rican strain. In this strain the frequency of late first anaphase figures showing a deviation from the normal 18 to 18 distribution was approximately 13 percent, appreciably lower than was found in P.I. 185641. As in the case of the latter strain, the second meiotic division in the other 36-chromosome strains was more regular than the first. The percentages of sporads with micronuclei were within the range of 5 to 16 percent, and pollen stainabilities ranged from 50 to 70 percent in plants of all of these strains.

Meiosis in the 43- and 48-chromosome plants was found to be relatively much less regular. Chromosome association at diakinesis and first metaphase in the 43-chromosome plant differed from that in the 36-chromosome plants primarily in a higher univalent frequency. Each of the 53 diakinesis cells analyzed contained one to nine univalents, and the mean frequency was 4.7 univalents per cell. Lagging chromosomes at first anaphase were found in 97 percent of the cells studied, and most of the cells contained 3 to 7 laggards. Second anaphase showed only slightly less irregularity than did the first, and 96 percent of the sporads contained one or more micronuclei. The mature pollen grains, of which 18 percent were stainable with IKI or acetocarmine, exhibited an appreciable variation in size.

The maximum chromosome association observed at diakinesis in the 48chromosome plants was $14_{\mathrm{IV}}+16_{\mathrm{II}}$, and several cells were found with $5_{\mathrm{IV}}+12_{\mathrm{II}}+4_{\mathrm{r}}$. On the basis of a limited sample of 21 diakinesis cells that could be completely analyzed, mean chromosome association in one of the 48-chromosome plants was $3.2_{\mathrm{IV}}, 0.2_{\mathrm{IIX}}, 13.3_{\mathrm{II}}$, and 7.4 . Approximately 98 percent of the first anaphase figures studied in each of these plants contained lagging chromosomes, with most cells having 5 to 14. The formation of micronuclei, commonly 6 to 12 per sporad, was found to occur in 95 to 98 percent of the sporads examined. Pollen-stainabilities of the two plants from which meiotic material was studied, and of three other plants of the same collection, were 5 to 9 percent.

Although meiosis in the aneuploid plants is relatively irregular, no evidence of aberrations in the spindles or in cytokinesis was found. The cell wall separating the two members of a first-division dyad is formed prior to 
the onset of the second division. The two second-division figures are essentially parallel to each other, resulting in the formation of the usual sporad or tetrad of microspores encountered in most monocotyledons.

\section{MEGASPOROGENESIS}

Differentiation of the archesporial cell from a hypodermal cell of the nucellus occurs at about the time the primordium of the inner integument is first apparent. At this stage the ovule is turned at an angle of about $90^{\circ}$ to the longitudinal axis of the floret. With subsequent growth the ovule rotates until it approaches an anatropous condition. After a period of elongation (fig. 1, A), during which the inner integument envelopes most of the' nucellus and the outer integument becomes well-defined, the archesporial cell occupies the full depth of the nucellus. During this period also there - is a proliferation of the cells in the micropylar region of the nucellar epidermis by one or more periclinal divisions. The outer cells in this region subsequently undergo a marked increase in size (fig. 1, B, et. seq.). This enlargement also was noted by Fisher, et al. (1).

The archesporial cell functions directly as the primary megasporocyte, and meiosis is initiated at about the same time that it is in microsporocytes of the same floret. Although observations were necessarily limited to a relatively small number of division figures, the first meiotic division appears to be comparable to that in microsporogenesis and results in the formation of a well-defined dyad (fig. 1, B). The chalazal member of the dyad subsequently undergoes a normal second meiotic division (fig. 1, C), which frequently fails to occur, or is not completed, in the micropylar cell (fig. $1, \mathrm{D})$. Meiosis may thus result in the formation of a linear tetrad, a linear triad, or rarely in a T-shaped tetrad of megaspores, depending upon the occurrence, completeness, and plane of the second meiotic division in the micropylar member of the dyad. The products of the meiotic divisions, with the usual exception of the chalazal megaspore, undergo a rapid degeneration soon after they are formed. The degenerating cells can be detected readily because of their shrunken appearance and dense stainability with hematoxylin (fig. 1, E, F).

\section{APOSPORY}

One or more enlarging nucellar cells, usually adjacent to the sporogenous material, frequently can be distinguished at the time of megasporogenesis, or shortly thereafter (fig. 1, F). In an occasional ovule the chalazal megaspore undergoes an early and presumably autonomous degeneration before the nucellar cells have enlarged very much. More typically, this megaspore persists as the nucellar cells enlarge. The megaspore characteristically lags in development, however, and often exhibits evidence of degeneration by 

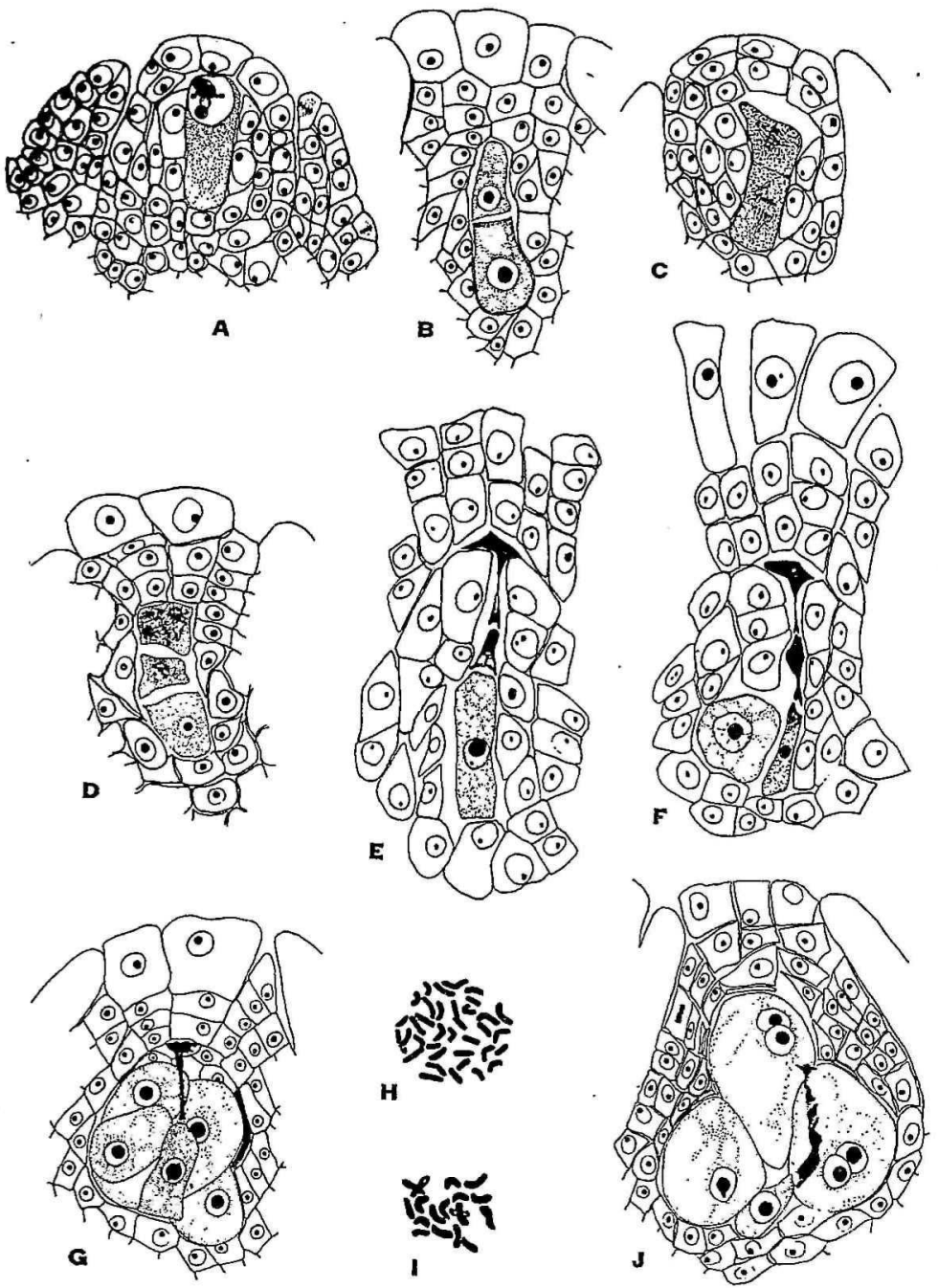

Frg. 1.-Camera lucida drawings of megasporogenesis and apospory in Pennisetum ciliare: A, Mature archesporial cell. B, Dyad resulting from first meiotic division. C, Second meiotic division. Note orientation and delay of division in micropylar cell. $D$, Second division complete in basal dyad, forming chalazal and adjacent megaspores. Division of micropylar dyad is incomplete. E, Chalazal megaspore enlarged, other megaspores degenerating. F, Degeneration of megaspores (including basal one) accompanied by enlargement of adjacent somatic cell of nucellus. G, Four enlarged nucellar cells and apparently normal basal megaspore. $\mathrm{H}$, Unreduced chromosome number, $2 n=36$, observed in mitotic division of enlarging nucellar cell. $\mathbf{I}$, Reduced number of chromosomes, $n=18$, from mitotic division of functional megaspore. J, Three young aposporic embryo sacs and remnants of megaspores. All except $\mathrm{H}$ and $\mathrm{I} \times 450 ; \mathrm{H}$ and $\mathrm{I} \times 1800$. 
the time the nucellar cells have undergone an appreciable increase in size (fig. 1, F, G). The chalazal megaspore can occasionally be seen, sometimes with the recognizable remains of the other sporogenous material, in ovules in which several nucellar cells and/or aposporic embryo sacs have attained appreciable development (fig. 1, J).

There are striking differences in appearance between persistent megaspores and enlarging nucellar cells. The former may exhibit a limited early increase in size, and infrequently an appreciable increase in size, but tend to remain elongate and the cytoplasm maintains a uniform appearance (fig. 1, G, J). The nucellar cells, on the other hand, rapidly increase in size and develop a rounded shape and highly vacuolate cytoplasm at an early stage. This is typical of aposporous behavior in many apomictic species. There is usually pronounced crowding and distortion in the region of the sporogenous material as the nucellar cells enlarge, which makes accurate interpretation difficult or impossible in many ovules. Observation of the stages immediately after formation of the megaspores in a large number of ovules of the various strains studied, indicates that development of a chalazal megaspore into a 2-nucleate embryo sac is a relatively rare occurrence in most of this material. Evidence which will be presented below, however, points to some variation among different strains in frequency of functioning of the megaspore.

An additional indication that the embryo sacs are predominantly derived from aposporic initials is found in the chromosome numbers of dividing embryo sac nuclei. Division figures were found in seven developing embryo sacs of P.I. 185641 and in five additional embryo sacs of the other strains studied. The diploid chromosome number, $2 n=36$, (fig. $1, \mathrm{H}$ ) could be counted in the mitotic figures in five of these embryo sacs, and in six of the remaining embryo sacs it was possible to obtain counts which approximated the diploid chromosome number. The only 4-nucleate embryo sac in process of division was found in P.I. 185641 and contained the reduced number of chromosomes, $2 n=18$, (fig. 1, I). The significance of this particular case, which establishes the fact that reduced embryo sacs are occasionally produced, will be discussed later.

\section{MEGAGAMETOGENESIS}

Development of the embryo sac, or female gametophyte, apparently follows two distinctly different patterns, which are closely comparable to those found in Panicum maximum (6). In the type of behavior that is predominantly represented in the present material, the two nuclei resulting from division in the embryo sac initial remain at the micropylar end of the developing embryo sac (fig. 2, A) - or at the end nearest the surface of the ovule in the case of widely displaced embryo sacs. A second division of these 
nuclei results in a 4-nucleate embryo sac in which the nuclei remain closely associated (fig. 2, B). Differentiation in these embryo sacs, without the occurrence of a third mitotic division, results in a mature gametophyte of the Oenothera type, with two synergids, an egg, and a polar nucleus (fig. $2, \mathrm{C})$.

In the second type of development, the nuclei in a young 2-nucleate embryo sac separate to opposite ends of the cell, and a large vacuole develops between them. These nuclei undergo a second division to form a 4-nucleate embryo sac (fig. 2, D, left), and subsequently a third division to produce an 8-nucleate embryo sac having four nuclei at each end (fig. 2, E). The 8-nucleate embryo sacs differentiate into mature gametophytes of the Polygonum type, having two synergids, an egg, two polar nuclei, and three antipodals. As is common among the grasses, the antipodals may undergo one or more additional division (fig. 2, F). Stages in development of 8-nucleate embryo sacs were relatively rare in the present material, and the process is apparently less frequent than it is in $P$. maximum.

Although all of the strains studied produce multiple embryo sacs, they differ considerably in the average number of embryo sacs per ovule. Data on the numbers of embryo sacs in five strains of $P$. ciliare and a single strain of $C$. setigerus, based on the study of ovules collected shortly before anthesis, are given in table 1. The highest mean number of embryo sacs per ovule, 4.6 in a sample of 78 florets, was found in P.I. 185641. Ovules containing 6 to 8 embryo sacs were frequently observed in this material, and no ovules with single embryo sacs were found in the sample studied. The other extreme is represented by P.I. 202513, in which a majority of the 33 ovules examined contained single embryo sacs and the mean number of embryo sacs per ovule was 1.5. The latter strain was the only one having an. appreciable number of sterile ovules, i.e., ovules in which no functional embryo sacs were formed, and exhibited the highest frequency of 8-nucleate embryo sacs. P.I. 202513 also differs from the other strains examined in the timing of development of the aposporic initials. Enlarging nucellar cells frequently are not well defined until some time after meiosis has been completed in the megasporocytes of this strain; whereas considerably enlarged aposporic initials are commonly found at a comparable stage of development in the other strains.

The multiple embryo sacs are usually crowded into the central part of the ovule and may occupy most of the former region of the nucellus by the time they are mature. Frequently, however, embryo sacs are found in the chalaza; in the periphery of the ovule, where they may invade and grossly disrupt the integuments; and in the funiculus, where they sometimes invade the tissue of the ovary wall. Most of these displaced embryo sacs apparently develop later than those occupying the central region of the ovule adjacent 


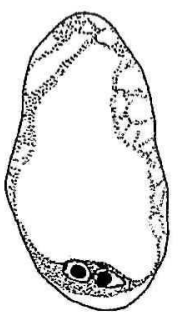

$\mathbf{K}$

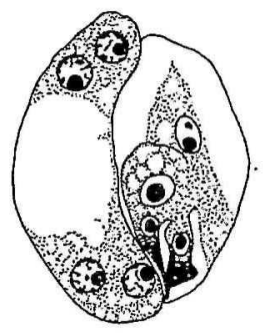

N

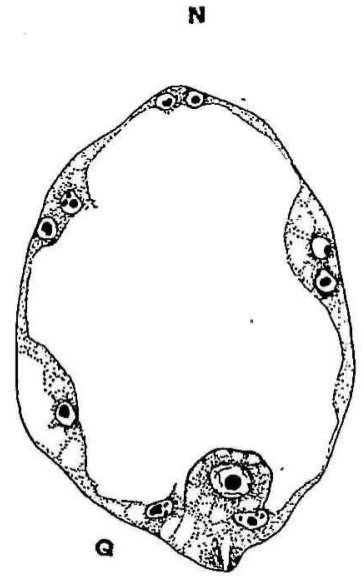

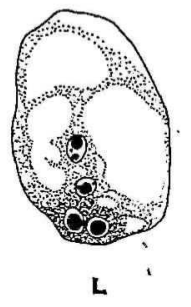
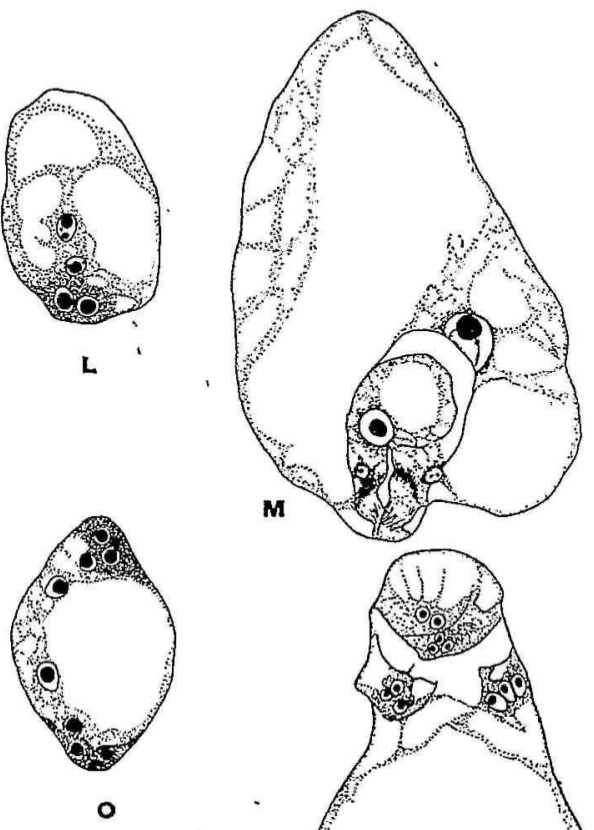

M

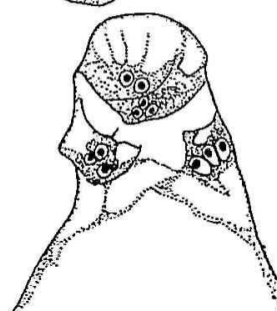

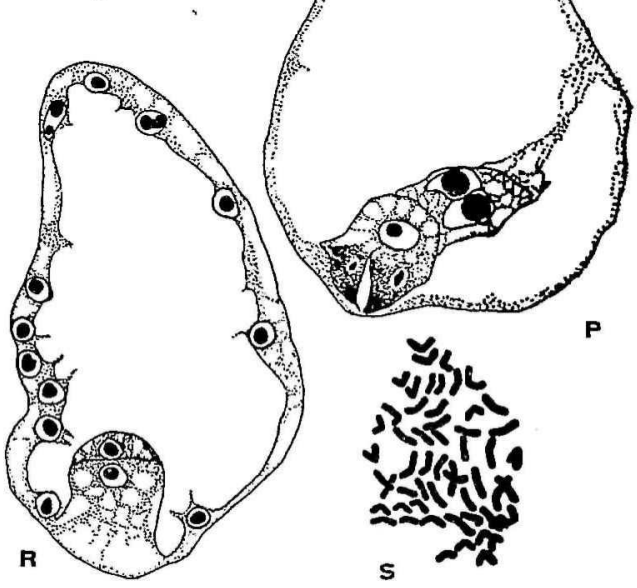

Frg. 2.-Embryo sac formation and early endosperm and embryo development in Pennisetum citiare: A, B, C, Development of 4-nucleate embryo sacs: A, 2-nucleate stage, both nuclei remaining at micropylar end. B, Early 4-nucleate stage. C, Mature 4-nucleate embryo sac containing 2 synergids, 1 egg, and 1 polar nucleus. D, E, F, Development of 8-nucleate embryo sacs: D, (left) 4-nucleate embryo sac with nuclei separated to opposite ends, with each nucleus in prophase of a third mitotic division. The embryo sac to the right is aposporic and differentiated at the 4-nucleate stage. E, Young 8-nucleate embryo sac. F, Mature embryo sac of 8-nucleate type, containing 2 synergids, $1 \mathrm{egg}, 2$ polar nuclei, and 3 antipodals (which have undergone further division). G, Embryo sac subsequent to fertilization. Endosperm is 16-nucleate; egg cell has not yet divided. H, Endosperm is 64-nucleate. The pre-embryo has undergone first division. I, Fifty-four chromosomes ( $3 n$ number) from early division in endosperm $1800 \times . A, B, D$, and $\mathrm{E}, 450 \times ; \mathrm{C}, \mathrm{F}, \mathrm{G}$, and $\mathrm{H}, 300 \times$. 
to the original sporogenous material. The orientation of the multiple embryo sacs is an interesting phenomenon. The egg apparatus tends to be oriented toward the nearest surface of the ovule, and may be directed at a $90^{\circ}$ angle or even a $180^{\circ}$ angle from the micropyle, depending upon the location of the particular embryo sac. This phenomenon also was observed by Fisher, et al. (1). Many embryo sacs, apparently often those in which development is initiated after several large embryo sacs are already present in the ovule, are crowded out by competition and fail to reach maturity.

\section{PSEUDOGAMY}

The structure of the inflorescence and size of the florets in $P$. ciliare make the effective emasculation of large numbers of florets very difficult.

TABLE 1.-Numbers of embryo sacs in ovules of 5 strains of Pennisetum ciliare and 1 strain of Cenchrus setigerus

\begin{tabular}{|c|c|c|c|c|c|c|c|c|c|}
\hline \multirow{2}{*}{ Strain } & \multicolumn{8}{|c|}{ Ovules per indicated number of embryo sacs } & \multirow{2}{*}{ Mean } \\
\hline & 1 & 2 & 3 & 4 & 5 & 6 & 7 & 8 & \\
\hline P.I. $185641 \ldots$ & 0 & 3 & 15 & 22 & 18 & 11 & 7 & 2 & 4.6 \\
\hline P.I. $156546 \ldots \ldots$ & 6 & 13 & 17 & 12 & 3 & 1 & 0 & 0 & 2.9 \\
\hline Puerto Rican . & 3 & 12 & 10 & 7 & 2 & 0 & 0 & 0 & 2.8 \\
\hline P.I. $193445 \ldots$ & 8 & 16 & 19 & 4 & 3 & 0 & 0 & 0 & 2.6 \\
\hline P.I. $1644141 \ldots$ & 14 & 17 & 11 & 5 & 0 & 0 & 0 & 0 & 2.2 \\
\hline P.I. $202513 \ldots$ & 22 & 7 & 2 & 2 & 0 & 0 & 0 & 0 & 1.5 \\
\hline
\end{tabular}

${ }^{1}$ Cenchrus setigerus.

As an alternative technique in studies to determine the role of pollination and fertilization in caryopsis development, entire stigmas were removed from florets at given intervals before and after anthesis. Ovaries from which the stigmas were removed within several hours before or after anthesis remained turgid and normal in appearance for as long as 48 hours and were apparently not damaged by the treatment. Moreover, removal of the stigmas at somewhat later stages did not affect seed set adversely.

Data on the relation between removal of the stigmas at various times and subsequent seed set are given in table 2 for two strains of $P$. ciliare. The results obtained in these strains, as well as less complete data obtained from a plant of P.I. 164414 that was later referred to $C$. setigerus, are closely comparable; although normal seed set in the various strains studied differs appreciably. Removal of the stigmas before anthesis or within $2 \frac{1}{2}$ hours after anthesis effectively eliminates seed production, presumably because growth of the pollen tube into the ovule is precluded: The formation of low percentages of seeds in treatments made during this interval probably re- 
flects faulty technique, e.g., incomplete removal of the stigmas from some florets. Removal of the stigmas 3 to $31 / 2$ hours after anthesis gives results intermediate between the earlier treatments and normal seed set. This result probably reflects the fact that some of the pollen tubes have completed their growth through the tissue of the stigmas by this time. Removal of the stigmas later than 4 hours after anthesis had no effect on seed set, the percentages of seeds produced in these cases being essentially the same as those obtained from samples of florets of the same age from which

TABLE 2.-Seeds set in florets of 2 strains of Pennisetum ciliare from which the stigmas were removed at given intervals before and after anthesis

\begin{tabular}{|c|c|c|c|c|}
\hline \multirow{2}{*}{ Strain } & \multirow{2}{*}{ Treatment: Stigmas removed- } & \multirow{2}{*}{$\begin{array}{l}\text { Florets } \\
\text { treated }\end{array}$} & \multicolumn{2}{|c|}{ Seeds set } \\
\hline & & & Number & Percent \\
\hline \multirow[t]{8}{*}{ P.I. 185641} & $36 \mathrm{hrs}$. before anthesis & 101 & $2^{\circ}$ & 2.0 \\
\hline & 0 to $1 / 2 \mathrm{hr}$. after anthesis & 115 & $\dot{1}$ & .9 \\
\hline & 1 to $11 / 2$ hrs. after anthesis & 188 & 7 & 3.7 \\
\hline & 2 to $21 / 2$ hrs. after anthesis & 115 & 2 & 1.7 \\
\hline & 3 to $31 / 2$ hrs. after anthesis & 121 & 35 & 28.9 \\
\hline & 4 to $41 / 2$ hrs. after anthesis & 124 & 112 & 90.2 \\
\hline & 5 to $51 / 2$ hrs. after anthesis & 99 & 87 & 87.9 \\
\hline & Control (stigmas not removed) & 284 & 243 & 85.6 \\
\hline \multirow{8}{*}{ P.I. 193445} & $36 \mathrm{hrs}$. before anthesis & 104 & 2 & 1.9 \\
\hline & 0 to $1 / 2 \mathrm{hr}$. after anthesis & 261 & 3 & 1.1 \\
\hline & 1 to $11 / 2 \mathrm{hrs}$. after anthesis & 109 & 0 & 0 \\
\hline & 2 to $23 / 2 \mathrm{hrs}$. after anthesis & 86 & 0 & 0 \\
\hline & 3 to $3 \frac{1}{2}$ hrs. after anthesis & 106 & 7 & 6.6 \\
\hline & 4 to $41 / 2$ hrs. after anthesis & 121 & 32 & 26.4 \\
\hline & 5 to $51 / 2 \mathrm{hrs}$. after anthesis & 114 & 39 & 34.2 \\
\hline & Control (stigmas not removed) & 352 & 112 & 31.8 \\
\hline
\end{tabular}

the stigmas had not been removed. The results obtained in this material are very similar to those reported by Warmke (6) for Panicum maximum.

The cytological examination of a large number of ovules, most of which were collected 8 to 12 hours after anthesis to obtain early endosperm divisions, revealed evidence of the growth of pollen tubes into one or more embryo sacs in a large majority of the ovules. Penetration of an embryo sac by a pollen tube is characteristically evidenced by a mass of cytoplasm intruded into the embryo sac, in the vicinity of the egg cell. In many embryo sacs, one or both synergids are crushed by entry of the pollen tube, although the nuclei of the synergids are ephemeral and usually have disappeared by the time the pollen tube enters the embryo sac. The deposition of darkstaining granules on the surface of the egg cell, associated with penetration 
of the pollen tube in Panicum maximum (6), was not found in the present material. An additional indication of the necessity of pollination, and presumably fertilization, for development of the caryopsis is found in the fact that neither the egg nor the polar nucleus divides in florets from which the stigmas have been removed at anthesis.

Only two embryo sacs containing early endosperm divisions in which the chromosome complement could be counted were found in several hundred ovules sectioned for this purpose. One of the division figures had 54 chromosomes (fig. 2, I), and the second, although the chromosomes could not be counted with certainty, had approximately that number. Both of these division figures were found in embryo sacs that originally had been 4-nucleate, as indicated by the absence of antipodal tissue, which persists until after fertilization in 8-nucleate embryo sacs. Thirty-six of the chromosomes in the dividing endosperm nuclei observed apparently were derived from an unreduced polar nucleus, and the remaining 18 chromosomes from a normal, reduced sperm nucleus.

The appearance of the egg cell in most embryo sacs containing 2-, 4- or 8-nucleate endosperms (fig. 2, G) strongly suggests that the egg usually is not fertilized-nor would such an event be expected. Division of the egg apparently is stimulated by development of the endosperm, and ordinarily takes place after the endosperm has reached a 16- to 32-nucleate condition (fig. 2, H). Occasionally, however, a multicellular embryo was seen where there was no endosperm development, either in the particular embryo sac or in other embryo sacs within the ovule. Various other infrequently encountered aberrations at this stage include development of a massive endosperm tissue with no division of the associated egg, and such phenomena in ovules containing multiple embryo sacs as development of a multicellular embryo not associated with any endosperm tissue in one embryo sac and an extensive endosperm associated with an individed egg cell in another embryo sac in the same ovule.

\section{POLYEMBRYONY}

In ovules containing several embryo sacs, some of the embryo sacs usually are located in a manner that makes their penetration by a pollen tube very unlikely. Cytological examination, however, indicates that frequently pollen tubes do grow into two or even three embryo sacs in an ovule. This is particularly true in P.I. 185641, which produces an average of 4.6 embryo sacs per ovule. The examination of later stages indicates the production of two embryos in approximately 20 percent of the ovules in this strain, with an occasional ovule having three embryos. The percentages of ovules containing multiple embryos are much lower in the other strains examined, as also are the average numbers of embryo sacs per ovule (table 1 ). The ger- 
mination of seeds of these strains on moist filter paper gives data which support the cytological observations. Twin seedlings were produced from 17.7 percent of the seeds of P.I. 185641, and from less than 3 percent of the seeds from the other strains involved in the investigation. In P.I. 164414 (C. setigerus), cytological examination revealed the formation of two embryos in occasional ovules, but no examples of twinning were found from 80 seeds germinated.

The production of multiple embryos in $P$. ciliare and $C$. setigerus results from the development of egg cells in separate embryo sacs; there is no indication of development of more than one egg in a given embryo sac, as sometimes happens in the production of multiple embryos in Poa pratensis (5). The formation of multiple embryos within multiple embryo sacs, involving phenomena closely comparable to those observed in the present material, has been observed in two additional species of Pennisetum, $P$. setaceum and $P$. villosum (4). In these species, as in $P$. ciliare, the embryos have a predominantly aposporic origin. The production of both aposporic and sexual embryo sacs in an occasional ovule (fig. 2, D), and the finding of an occasional chalazal megaspore, without enlarging nucellar cells (fig. 1, E), however, suggests the possibility of an infrequent sexual embryo.

\section{DISCUSSION}

Recent investigations have established the occurrence of apomictic phenomena in several species of Pennisetum and in a single species of Panicum, in the grass tribe Paniceae. In a broad survey of reproductive processes in a number of Pennisetum species, Narayan (4) has reported that $P$. villosum is an obligate apomict, and that $P$. clandestinum, and possibly $P$. orientale are facultative apomicts. In addition, Narayan found evidence of apospory and possible facultative apomixis in the examination of limited material of $P$. ramosum. Warmke (6) has recently reported the occurrence of facultative apomixis in five agronomic varieties of Panicum maximum, with details of the mechanisms involved. After the present study had been completed, Fisher, et al. (1), as the result of concurrent investigations, reported evidence for the occurrence of apomixis in $P$. ciliare and $C$. setigerus.

The reproductive behavior observed in the present material exhibits many similarities to that found in Panicum maximum. As in the latter species, a striking phenomenon is the production of mature embryo sacs of two distinctly different types; the predominant type being 4-nucleate and the much less frequent type 8-nucleate. Pennisetum ciliare and Cenchrus setigerus thus provide a fifth and sixth example, with Pennisetum orientale, $P$. setaceum, $P$. villosum, and Panicum maximum, of the production of mature 4-nucleate embryo sacs outside the family Onagraceae. It is un- 
doubtedly significant that all of these species, in three closely related genera, are aposporous and probably also pseudogamous apomicts.

Although it was not possible to determine with certainty whether there was a consistent difference in chromosome number between the two types of embryo sacs in Panicum maximum (6), appreciable evidence pointed toward the conclusion that the 4-nucleated type of embryo sac was usually unreduced and the 8-nucleate type was at least sometimes reduced. The incidence of 8-nucleate embryo sacs tends to be lower in.Pennisetum ciliare than in Panicum maximum. Evidence from the examination of hundreds of ovules is consistent with that general conclusion. The apparent infrequent development of chalazal megaspores correlates well with the subsequent low incidence of 8-nucleate embryo sacs. In addition, 11 of the 12 embryo sacs in which chromosome counts could be obtained were unreduced. All of these unreduced embryo sacs in which development had progressed to the 2-nucleate condition had the two nuclei located at one end, i.e., the embryo sacs were apparently destined to be 4-nucleate. It is a matter of appreciable interest that the only 4-nucleate embryo sac in which division was observed contained the reduced number of chromosomes, thus providing critical evidence that at least some of the 8-nucleate embryo sacs are derived from functional megaspores.

\section{SUMMARY}

Cytological studies of seven collections of Pennisetum ciliare from widely separated locations indicate that apomixis, including apospory and pseudogamy, is the predominant mode of reproduction in this highly variable species. Chromosome numbers of $2 n=43$ and $2 n=48$ were found, in addition to the numbers $32,36,40$, and 54 previously reported for this species. Meiotic behavior in PMC's varies widely in the different strains, but, in general, is characterized by limited quadrivalent formation and considerable irregularity and chromosome nondisjunction. The products of meiosis in the ovules usually degenerate soon after they are formed, and one or more cells of the nucellus enlarge to become unreduced embryo sacs. Both 4- and 8-nucleate mature embryo sacs are produced, the latter being relatively uncommon, however. Evidence from Panicum maximum and the materials involved in the present study strongly suggests that mature 4-nucleate embryo sacs are typically unreduced and that 8-nucleate embryo sacs are typically reduced in these species. Pollination is necessary for the initiation of divisions in the endosperm, which precede the division of the unreduced and unfertilized egg. Closely comparable reproductive behavior was found in material of a single collection of Cenchrus setigerus. 


\section{RESUMEN}

El estudio citológico de especímenes de Pennisetum ciliare de siete colecciones procedentes de distintas regiones, reveló que en esta especie tan variable las formas predominantes de reproducción son aposporia y pseudogamia. Además de los números diploides $32,36,40$, y 54, informados anteriormente, se encontraron también los de 43 y 48 . Aunque el proceso meyótico en las células madres es muy distinto en las diferentes variedades, el mismo se caracteriza, en términos generales, por pocas agrupaciones cuadrivalentes, considerable irregularidad y no-disyunción cromosómica. Los productos de la meyosis en los óvulos casi siempre degeneran poco después de haberse formado y una o más células de la nucela, al aumentar de tamaño, se convierte en sacos embrionales no reducidos. Se forman dos tipos de sacos embrionales maduros, unos con cuatro núcleos y otros con ocho, pero éstos últimos son relativamente escasos. Este estudio, así como otros practicados con Panicum maximum, parecen indicar que en estas dos especies los sacos embrionales maduros dotados de 4 núcleos son normalmente no reducidos, mientras que los de ocho núcleos son reducidos. La polinización es necesaria para que el endosperma comience a dividirse, proceso que antecede a las divisiones que se verifican en el óvulo no reducido y no fecundado. Una forma de reproducción muy parecida a.la descrita se observó también en especímenes de una colección de Cenchrus setigerus.

\section{LITERATURE CITED}

1. Fisher, W. D., Bashaw, E. C., and Holt, E. C., Evidence for apomixis in Pennisetum ciliare and Cenchrus setigerus, Agron. J. 46 401-4, 1954.

2. Garcia-Molinari, O., Grasslands and grasses of Puerto Rico, Bul. 102, Puerto Rico Agr. Exp. Sta., Río Piedras, P. R., 1952.

3. Hernández, Alice R., Observations on the chromosome number of Pennisetum ciliare, J. Agr. Univ. P.R. 37 161-70, 1953.

4. Narayan, K. N., Cytogenetic studies of apomixis in Pennisetum, Ph.D. thesis, Univ. Calif., Berkeley, Calif., 1951.

5. Nielsen, E. L., The origin of multiple macrogametophytes in Poa pratensis, Bot. Gaz. 10841-50, 1946.

6. Warmke, H. E., Apomixis in Panicum maximum, Amer. J. Bot. 41 5-11, 1954. 